\title{
Pengaruh Pendekatan saintifik berbantuan media Power Point Terhadap Disposisi Matematika Siswa SMP Negeri 6 Kota Bengkulu
}

\author{
${ }^{1}$ Eka Novrianti Prana Putri, ${ }^{2}$ Saleh Haji \\ ${ }^{1,2}$ Program Studi Pascasarjana Pendidikan Matematika FKIP Universitas Bengkulu \\ Koresponden: ekagupran@gmail.com
}

\begin{abstract}
Abstrak
Penelitian ini bertujuan untuk mengetahui apakah terdapat pengaruh serta perbedaan pendekatan saintifik berbantuan media Power Point terhadap disposisi matematika siswa SMP N 6 Kota Bengkulu dengan mengontrol kemampuan awal disposisi matematika Penelitian ini merupakan penelitian Eksperimen. . Populasi dalam penelitian ini adalah siswa kelas VII kelas yaitu VII A, VII B, VII C, VII D, VII E dan VII F SMP N 06 Kota Bengkulu tahun pelajaran 2017/2018 dengan jumlah siswa laki-laki sebanyak 106 siswa dan perwmpuan 111 siswa. Instrumen penilaian disposisi matematika yang dikembangkan dalam penelitian ini berupa angket disposisi matematika. Hasil penelitian ini adalah sebagai berikut: nilai signifikan disposisi pada tabel kecil dari 0,05 maka terima $\mathrm{H}_{1}$, berarti Terdapat pengaruh penerapan pendekatan saintifik berbantuan media powerpoint terhadap terhadap kemampuan disposisi matematika. Besarnya pengaruh perlakuan pertama terhadap disposisi matematika adalah $66,1 \%$
\end{abstract}

Kata Kunci : Pendekatan Saintifik, Media Powerpoint, Disposisi matematika

\section{Abstract}

This study aims to determine whether there is an influence and differences of the scientific approach assisted Power Point media on the mathematical disposition of students of SMP N 6 Bengkulu City by controlling the initial ability of mathematical dispositions. This research is an experimental research. . The population in this study are the students of class VII class namely VII A, VII B, VII C, VII D, VII E and VII F SMP N 06 Bengkulu City year lesson 2017/2018 with the number of male students as much 106 students and 111 students. The mathematical disposition assessment instrument developed in this research is a questionnaire of mathematical disposition. The results of this study are as follows: the significant value of disposition in the table is small than 0.05, then accept H1, meaning that there is an effect of the application of the scientific approach assisted by powerpoint media on the mathematical disposition ability. The magnitude of the effect of the first treatment on mathematical disposition was $66.1 \%$

Keywords: Scientific Approach, Powerpoint Media, Math Disposition 


\section{Pendahuluan}

Matematika merupakan ilmu universal yang mendasari perkembangan teknologi modern, mempunyai peran penting dalam berbagai disiplin dan memajukan daya pikir manusia. (Depdiknas, 2007). Bidang studi matematika diajarkan kepada siswa sejak SD hingga di perguruan tinggi. Dalam hal ini bisa terlihat bahwa matematika memiliki peran yang sangat penting dalam ranah pendidikan. Melalui pembelajaran matematika diharapkan siswa dapat menumbuhkan kemampuan berfikir kritis, logis, sistematis, dan cermat dalam memecahkan masalah. Tercapai atau tidaknya tujuan pendidikan dan pembelajaran matematika salah satunya dapat dilihat dari keberhasilan siswa dalam memahami matematika dan memanfaatkan pemahaman tersebut untuk menyelesaikan persoalan-persoalan matematika. Berdasarkan hasil wawancara awal tanggal 24 Januari 2017 yang dilakukan peneliti kepada guru matematika SMP N 6 Kota Bengkulu, menyatakan bahwa pembelajaran matematika masih sebagai momok yang menakutkan terbukti dari pengalaman pengajaran. Misalnya pada materi garis dan sudut siswa masih kesulitan dalam memecahkan permasalahan yang ada pada materi tersebut. Kesulitan siswa juga terlihat pada kemampuan siswa dalam mengenal beberapa simbol dalam matematika.

Menurut NCTM (2000) disposisi matematis adalah kecenderungan untuk berpikir dan bertindak dengan cara yang positif. Kecenderungan ini tercermin oleh kepentingan dan keyakinan siswa dalam melakukan matematika, kemauan untuk mengeksplorasi alternatif dan bertahan sementara memecahkan masalah matematika, dan kesediaan untuk merefleksikan pemikiran mereka sendiri sementara mereka belajar matematika.

Beyer (2011) describes the term "disposition towards mathematics" or "Mathematical disposition" as including three mental models, "cognitive, affective, and conative" which are directly related to students' or teachers' beliefs about the nature of mathematics, the level of difficulty in mathematics, and their attitudes towards mathematics. Consequently, a person's disposition towards mathematics, affects his/her willingness to "engage in a mathematical context (e.g. doing and/or learning mathematics)" . Pendapat yang dikemukakan oleh Beyers (2011), menggambarkan istilah "disposisi terhadap matematika" atau "disposisi matematika" termasuk dalam tiga model mental yaitu, "kognitif, afektif, dan konatif" yang berhubungan langsung dengan keyakinan siswa atau guru tentang sifat matematika, tingkat Kesulitan dalam matematika, dan sikap mereka terhadap matematika. Akibatnya, disposisi seseorang terhadap matematika, mempengaruhi kesediaannya untuk terlibat dalam konteks matematis (misal: melakukan atau belajar matematika)"

Berdasarkan uraian di atas dapat disepakati bahwa disposisi matematika siswa dalam kegiatan pembelajaran matematika perlu mendapat pembenahan, sebab jika tidak akan menghasilkan kemampuan menyerap materi pelajaran yang rendah. Dari uraian di atas penulis berkeinginan untuk melakukan penelitian tentang "Pengaruh Pendekatan saintifik berbantuan media Power Point Terhadap Disposisi Matematika Siswa SMP Negeri 6 Kota Bengkulu”.

Tujuan penelitian ini adalah Untuk (1)mengetahui apakah terdapat pengaruh pendekatan saintifik berbantuan media Power Point terhadap disposisi matematika siswa SMP N 6 Kota Bengkulu dengan mengontrol kemampuan awal disposisi matematika, (2)mengetahui apakah ada pengaruh linier kovariat kemampuan awal pemecahan masalah terhadap rerata kemapuan akhir pemecahan masalah siswa kelas eksperimen SMP N 6 Kota Bengkulu yang belajar dengan 
pendekatan saintifik dengan siswa kelas kontrol yang belajar dengan model pembelajaran konvensional dan (3)Untuk mengetahui apakah terdapat perbedaan disposisi matematika yang diajarkan dengan pendekatan saintifik berbantuan media Media Interaktif Virtual lebih baik dari siswa yang diajarkan menggunakan pembelajaran konvensional dengan mengontrol kemampuan awal disposisi matematika.

Hasil penelitian diharapkan dapat bermanfaat bagi berbagai pihak, diantaranya yaitu : (1) Bagi siswa, membantu siswa untuk meningkatkan cara belajar yang baik, efektif, efisien dan mengembangkan keinginan dan kesadaran siswa supaya lebih memahami pembelajaran matematika (2)Bagi guru, membantu guru untuk menambah wawasan bagaimana mengajar siswa memecahkan masalah matematika dan disposisi matematika siswa, (3) Bagi sekolah, sebagai bahan pertimbangan dan masukan dalam upaya meningkatkan kualitas belajar mengajar siswa.

\section{Metode Penelitian}

Jenis penelitian yang dilkuakan dalam penelitian ini adalah penelitian eksperimen. Penelitian ini dilaksananakan di SMP N 06 Kota Bengkulu tahun ajran 2017/2018 pada semester genap. pada materi garis dan sudut. Adapun Tahapan-tahapan dalam penelitian ini adalah: (1) Tahap Persiapan, (2) Tahap Perlakuan (3) Tahapan Analisis dan (4) Tahap Penyelesaian. Subjek penelitian ini adalah siswa SMP N 06 Kora Bengkulu tahun ajaran 2017/2018.

Teknik pengumpulan data dalam penelitian ini adalah menggunakan lembar tes dan angket. Lembar tes yang dimaksud adalah tes kemampuan pemecahan masalah dan lembar angket yang dimaksud untuk mengukur disposisi matematis siswa, masing-masing terdiri dari dua macam yaitu lembar untuk pretest (tes awal) dan lembar untuk post test (tes akhir). Kegunaan dilakukannya tes awal ini untuk mendapatkan data kemampuan pemecahan masalah dan sdisposisi matematis siswa sebelum diberi perlakuan dengan menggunakan metode yang telah dipilih.

Analisis data dalam penelitian ini adalah kegiatan yang dilakukan setelah semua data terkumpul dari seluruh responden kegiatan dalam analisis data adalah; mengelompokkan data berdasarkan variabel dari seluruh responden, menyajikan data tiap variabel yang diteliti, melakukan perhitungan untuk menjawab rumusan masalah dan melakukan perhitungan untuk menguji hipotesis yang telah diajukan. Adapun langkah-langkah dalam analisis data pada penelitian ini terdiri dari: (1)Analisis Deskriptif dilakukan dengan mendeskripsikan data hasil penelitian melalui table distribusi frekuensi dan histogr, (2) Uji Persyaratan Analisis yang meliputi uji normalitas, data, uji homogenitas, dan uji linearitas dan (3)Uji Hipotesis Dari hasil tes pretest dan post test kemampuan kemampuan pemecahan masalah dan angket disposisi matematika siswa yang telah diperoleh kemudian dianalisis dengan menggunakan ANCOVA (Analysis of Covarians) yang termasuk dalam Statistik Parametis. Penggunaan Anakova ini digunakan untuk melakukan pengujian hipotesis komparatif dua sampel secara bersama-sama.

\section{Hasil Penelitian}

Penelitian ini dilaksanakan di kelas VII SMPN 6 Negeri Kota Bengkulu dengan mengambil sampel 2 kelas yaitu Kelas VII A untuk eksperimen dan untuk kelas kontrol yaitu Kelas VIIB.

Proses pelaksanaan pembelajaran dilaksanakan berdasarkan RPP yang telah dirancang sebelumnya oleh peneliti, dengan pendekatan pembelajaran saintifik berbatuan Media Powerpoint untuk kelas eksperimen dan pembelajaran konvensional untuk kelas kontrol. 
Kegiatan pembelajaran pada penelitian ini diawali dengan memberikan pretes atau tes awal kepada seluruh sampel baik kelas eksperimen maupun di kelas kontrol, hal ini dimaksudkan untuk mengetahui tingkat kemampuan dasar siswa sebelum diberikan perlakuan. Pemberian pretes di SMPN 6 Negeri Kota Bengkulu dilakukan pada tanggal 7 Mei 2018 untuk kelas eksperimen dan kelas kontrol.

Kegiatan pembelajaran pada penelitian pada penelitian ini dilaksanakan ada dalam 6 kali pertemuan yang terbagi atas; satu kali pretes, 4 kali pertemuan kegiatan pembelajaran yang terbagi menjadi empat pokok pembahasan yaitu; Garis, Hubungan dua garis, Sudut, Penggunaan garis dan Sudut dalam dunia nyara. Satu pertemuan untuk postes Disposisi Matematika.

Disposisi matematika dilaksanakan sebelum diberikan perlakuan pembelajaran pada setiap kelas penelitian. Angket dilaksanakan dengan menggunakan 40 pernyataan. Hasil disposisi matematis siswa dengan menggunakan skala penilaian 40-160 pada setiap kelas penelitian seperti pada Tabel 1 berikut :

Tabel 1 Data Tes Awal Disposisi Matematika Siswa Pada Kelas Penelitian

\begin{tabular}{|c|c|c|c|c|}
\hline \multirow{2}{*}{ Kelas Penelitian } & \multicolumn{4}{|c|}{ Deskripsi Data } \\
\cline { 2 - 5 } & Min & Maks & Mean & Std. Deviation \\
\hline Eksperimen & 50 & 78 & 61,32 & 7,35 \\
\hline Kontrol & 53 & 78 & 64,32 & 7,09 \\
\hline
\end{tabular}

Data pada Tabel 1 menunjukkan bahwa nilai rata-rata disposisi kelas eksperimen yaitu sebesar 61,32 dengan nilai tertinggi 78 dan nilai terendah 50. Sedangkan pada kelas kontrol (pembelajaran konvensional) nilai rata-rata kemampuan Pemecahan Masalah siswa adalah 64,32 dengan nilai tertinggi 78 dan nilai terendah 53. Nilai standar deviasi pada kelas eksperimen 7,35 dan 7,09 pada kelas kontrol. Hasil menunjukkan rata-rata nilai pada kedua kelas identik sama.

Hasil disposisi matematis siswa dengan menggunakan skala penilaian 40-160 pada setiap kelas penelitian seperti pada Tabel 2 berikut

Tabel 2 Data Tes Akhir Disposisi Matematika Siswa Pada Kelas Penelitian

\begin{tabular}{|c|c|c|c|c|}
\hline \multirow{2}{*}{ Kelas Penelitian } & \multicolumn{4}{|c|}{ Deskripsi Data } \\
\cline { 2 - 5 } & Min & Maks & Mean & Std. Deviation \\
\hline Eksperimen & 119 & 155 & 135,59 & 8,30 \\
\hline $\begin{array}{c}\text { Kontrol } \\
(\text { Konvensional) }\end{array}$ & 100 & 133 & 117,73 & 8,11 \\
\hline
\end{tabular}


Data pada Tabel 2 menunjukkan bahwa nilai rata-rata disposisi kelas eksperimen yaitu sebesar 135,59 dengan nilai tertinggi 155 dan nilai terendah 119. Sedangkan pada kelas kontrol (pembelajaran konvensional) nilai rata-rata disposisi siswa adalah 117,73 dengan nilai tertinggi 133 dan nilai terendah 100. Nilai standar deviasi pada kelas eksperimen 8,30 dan 8,11 pada kelas kontrol. Hasil menunjukkan rata-rata nilai kelas eksperimen lebih besar sehingga secara umum disposisi siswa dengan diberikan pembelajaran dengan model Pendekatan pembelajaran saintifik berbatuan Media Powerpoint lebih tinggi dari siswa yang diberikan pembelajaran konvensional.

Berdasarkan skor yang telah dianalisis, hasil disposisi matematika siswa menunjukkan bahwa kelas eksperimen memiliki rata-rata lebih tinggi yakni 135,59 dibandingkan dengan kelas kontrol yaitu 117,73. Pendekatan Pendekatan pembelajaran saintifik berbatuan Media Powerpoint membuat siswa lebih aktif dan rasa ingin tahu yang tinggi merupakan faktor yang mempengaruhi hasil belajar siswa, penggunaan model pembelajaran yang dilakukan sehingga siswa memiliki disposisi matematika yang lebih tinggi. Pembelajaran ini juga menumbuhkan rasa percaya diri siswa lebih besar sehingga motivasi siswa menjadi meningkat.

Faktor lainnya adalah materi yang diberikan kepada siswa selalu berkaitan dengan permasalahan yang biasa ditemui siswa sehari-hari sehingga siswa lebih cepat menangkap maksud dari materi yang diberikan. Sedangkan pada kelas kontrol pembelajaran dilakukan dengan konvensional terlihat siswa belajar seperti biasanya, mendengarkan ceramah guru, mengerjakan latihan dan menjawab soal-soal. Kegiatan belajar seperti ini membuat siswa cepat bosan dan tidak bersemangat untuk memahami mmateri dengan baik. Siswa menjadi malas berfikir dan hanya menunggu instruksi dari guru.

Berdasarkan hasil uji analisis yang telah dilakukan dengan program SPSS menghasil nilai Sig $(0,000)<0,05$ pada tabel tests of between subjects effect, maka dihasilkan hipotesis Ho ditolak pada taraf signifikansi 0,05 artinya dengan menggunakan taraf signifikasi 5\% terdapat perbedaan disposisi matematika antara siswa yang mengikuti pembelajaran pembelajaran saintifik berbatuan Media Powerpoint dengan pembelajaran konvensional. Hal ini memberikan kesimpulan bahwa pendekatan pembelajaran saintifik berbatuan Media Powerpoint memberikan pengaruh terhadap disposisi matematika siswa.

Besar pengaruh pendekatan pembelajaran saintifik berbatuan Media Powerpoint dapat dilihat pada tabel tests of beetween subject effect yang menunjukkan nilai 0.661. Ini berarti pembelajaran tersebut memiliki efek terhadap disposisi matematika sebesar $66.1 \%$.

Besar pengaruh dari nilai tersebut memberikan gambaran bahwa pendekatan pembelajaran saintifik berbatuan media Powerpoint sangat memberikan efek pada disposisi matematika siswa. Selain itu permasalah yang diberikan dalam pembelajaran Pendekatan pembelajaran saintifik berbatuan Media Powerpoint dapat digunakan siswa untuk mengeksplorasi kompetensi yang dimiliki serta dapat mengembangkan kemampuan berfikir siswa dalam memahami materi matematika.

Selain itu hasil pengamatan yang dilakukan peneliti dalam pembelajaran dengan Pendekatan Pendekatan pembelajaran saintifik berbatuan Media Powerpoint menjadikan siswa berpartisipasi aktif dalam pembelajaran. Ketika berlangsung pembelajaran siswa terlihat memanfaatkan waktu dengan aktif bertanya dan berdiskusi dalam menyelesaikan masalah matematika yang diberikan guru. Siswa menemukan sendiri proses untuk materi matematika, berusaha mandiri, dan fleksibel dalam menyelesaikan masalah matematika. Sehingga rasa percaya diri siswa meningkat. Peningkatan disposisi terlihat dari perubahan cara siswa menyelesaikan masalah matematika terkait dengan materi matematika yang diberikan oleh guru. Hal senada 
diperoleh bahwa memanfaatan media pembelajaran kontekstual yang tepat dan sesuai dengan kebutuhan, dapat meningkatkan kemampuan siswa dalam proses pencapaian konsep dan prinsip matematika serta meningkatkan ketuntasan belajar siswa (Widada, 2015) (Widada, 2004). The students' mathematical communication abilities taught with realistic mathematics learning approaches are higher than those taught by traditional learning approaches. Also, the average ability of the students' mathematics communication learned using the ethnomathematics-oriented material was higher than those given non-ethnomathematics (Widada, Herawaty, Yanti, \& Izzawati, 2018). Juga, direct effect of cognitive conflict covariate on the mean of comprehension ability concept for students taught by Contextual Learning Model better than Conventional Learning Model; and The direct influence of cognitive conflict covariates on mean ProblemSolving Ability for students taught by Contextual Learning Model is better than Conventional Learning Model (Herawaty \& Widada, 2018).

\section{Simpulan Dan Saran}

Berdasarkan uraian hasil penelitian ini, maka dapat disimpulkan sebagai berikut: Ada pengaruh pendekatan saintifik berbantuan media Power Point terhadap disposisi matematika siswa SMP N 6 Kota Bengkulu dengan mengontrol kemampuan awal disposisi matematika; Tidak ada pengaruh linier kovariat awal disposisi matematika terhadap rerata kemapuan akhir disposisi matematika siswa kelas eksperimen SMP N 6 Kota Bengkulu yang belajar dengan pendekatan saintifik berbantuan media Power Point dengan siswa kelas kontrol yang belajar dengan model pembelajaran konvensional; Ada perbedaan disposisi matematika yang diajarkan dengan pendekatan saintifik berbantuan media Power Point lebih baik dari siswa yang diajarkan menggunakan pembelajaran konvensional dengan mengontrol kemampuan awal disposisi matematika.

Berdasarkan simpulan penelitian ini , maka peneliti memberikan beberapa saran sebagai berikut: Karena model pembelajaran saintifik dengan berbantuan media powerpoint memberikan pengaruh positif terhadap didposisi matematika siswa SMP N 6 Kota Bengkulu, maka disarankan kepada guru atau perancang pembelajaran matematika dapat menerapkan pengembangan lebih lanjut model pembelajaran saintifik dengan berbantuan media powerpoint untuk dapat meningkatkan disposisi matematika siswa.

\section{DAFTAR PUSTAKA}

Depdiknas. (2007). Peraturan Menteri Nasional Republik Indonesia Nomor 22 Tahun 2007 tentang Standar isi,standar kompetensi,dan kompetensi dasar. Badan Standar Nasional Pendidikan,Jakarta.

Beyer, J. (2011). Development and evaluation of an instrument to assess prospective teachers' dispositions with respect to mathematics. International Journal of Business and Social Science, 2 (16), hlm. 20-32

Herawaty, D., \& Widada, W. (2018). The Influence of Contextual Learning Models and the Cognitive Conflict to Understand Mathematical Concepts and Problems Solving Abilities. Advances in Social Science, Education and Humanities Research, 218(ICoMSE 2017), 96- 
102. https://doi.org/10.2991/icomse-17.2018.17

Widada, W. (2004). Pendekatan Pembelajaran Matematika Berbasis Masalah. Surabays: Unipa Press.

Widada, W. (2015). Proses Pencapaian Konsep Matematika dengan Memanfaatkan Media Pembelajaran Kontekstual. Jurnal Penelitian Pendidikan Matematika Dan Sains, 22(1), 3144. Retrieved from https://id.wikipedia.org/wiki/Pembelajaran

Widada, W., Herawaty, D., Yanti, D., \& Izzawati, D. (2018). the Student Mathematical Communication Ability in Learning Etnomathematics Orieted Realistic Mathematics. International Journal of Science and Research (IJSR), 7(9), 881-884. https://doi.org/10.21275/ART20191277 